\title{
RESILIENT MODERNISATION: MOROCCO'S AGENCY IN RED CROSS PROJECTS FROM HASSAN I TO THE RIF REPUBLIC, 1886-1926
}

\author{
Francisco Javier Martínez-Antonio \\ Univ. Paris Diderot, Sorbonne Paris Cité, SPHERE, UMR 7219 CNRS - F-75013, Paris, France \\ franciscojavier_martinez@yahoo.com
}

Received: 8 October 2013; Accepted: 22 January 2014.

Citation/Cómo citar este artículo: Martínez-Antonio, F. J. (2014), "Resilient modernisation: Morocco's agency in Red Cross projects from Hassan I to the Rif Republic, 1886-1926", Asclepio 66 (1): p032, doi: http://dx.doi.org/10.3989/asclepio.2014.06

\begin{abstract}
From the end of the $19^{\text {th }}$ to the beginning of the $20^{\text {th }}$ century, Morocco's modernizing projects included plans for signing up to the Geneva Convention and creating a local Red Cross/Crescent society. These plans initially stemmed from the convergence of Moroccan administrative/military reforms and Spanish "regenerationist" interventions. They ran parallel to developments in leading Islamic countries such as Egypt, Persia and the Ottoman Empire though they would have to wait till the country's independence from Franco-Spanish domination in 1956 to become a reality. Beyond their lack of actual results, those early initiatives would serve as legal ground for Morocco's "humanitarian sovereignty", tacitly confirmed by the provisions of the Algeciras Act of 1906. In the following two decades, the resilience of this sovereignty would reveal itself in the sustained competition between the Spanish and the French Red Cross for "humanitarian hegemony" in the country, and also in the repeated and nearly successful demands to establish a local Red Cross/Crescent that were made to the International Committee of the Red Cross by the insurgent leader Abdelkrim during the so-called Rif War.
\end{abstract}

KEY WORDS: Morocco; $19^{\text {th }}-20^{\text {th }}$ centuries; Red Cross; local agency; Franco-Spanish imperialism.

MODERNIZACIÓN RESILIENTE: LA CRUZ ROJA EN MARRUECOS DE HASSAN I A LA REPÚBLICA DEL RIF $(1886-1926)$

RESUMEN: Hacia finales del siglo XIX y comienzos del XX, los proyectos de modernización de Marruecos incluyeron planes de adhesión a la Convención de Ginebra y de creación de una sociedad local de la Cruz/Media Luna Roja. Estos planes surgieron de la convergencia entre las reformas administrativas/militares marroquíes y las intervenciones "regeneracionistas" españolas. Transcurrieron en paralelo con los desarrollos en países islámicos líderes como Egipto, Persia y el Imperio Otomano, aunque habrían de esperar para hacerse realidad hasta la independencia del país de la dominación franco-española en 1956. Más allá de la falta de resultados concretos, estas tempranas iniciativas servirían como marco legal a la "soberanía humanitaria" de Marruecos, tácitamente confirmada mediante las cláusulas del Acta de Algeciras de 1906. Durante las siguientes dos décadas, la resiliencia de esta soberanía se haría patente en la competición entre la Cruz Roja Española y la Francesa por la "hegemonía humanitaria" en Marruecos, así como en las repetidas y casi exitosas demandas para el establecimiento de una Cruz/Media Luna Roja rifeña, que hizo al Comité Internacional de la Cruz Roja el líder insurgente Abdelkrim durante la Guerra del Rif.

PALABRAS CLAVE: Marruecos; siglos XIX-XX; Cruz Roja; agencia local; imperialismo franco-español.

Copyright: (c) 2014 CSIC. This is an open-access article distributed under the terms of the Creative Commons Attribution-Non Commercial (by-nc) Spain 3.0 License. 


\section{INTRODUCTION}

During the 19th century, Islamic countries such as the Ottoman Empire, Egypt and Persia launched programs of reform aimed at modernising the structures of their armies, State bureaucracies and economies in an effort to deal with the growing challenges posed by European hegemony in the world (Al-Sayyid, 1984; Moreau, 2007; Moreau 2009). Traditionally, these programmes have been analysed in terms of export, transfer or diffusion of ideas and institutions from Western/European centres to Islamic peripheries by imperialist enforcement. However, they might be better described and understood as part of a global process of modernisation which involved the simultaneous and connected emergence of modern societies in various parts of the world with specific paths and outcomes in each particular locality. The modernisation of science, technology and medicine (STM) in Islamic countries, a very relevant component of the aforementioned reform plans (Longuenesse, 1995; Anastassiadou-Dumont, 2003; Crozet, 2008; Moulin, Ulman, 2010), could be similarly conceived. Modern STM would have originated and developed not only in Europe or the West but in various locations throughout the world as a result of "reciprocal, although asymmetric processes of circulation" of ideas, practices and objects (Raj, 2010, p. 8, 13). Accordingly, it should be viewed as "an integral part in the history of medicine beyond the West" (Ebrahimnejad, 2005, p. 3). This would mean abandoning the conceptualisation of STM in terms of self-contained "systems", such as "Islamic science" or "Western science" and acknowledging the continuities existing between tradition and novelty, the old and the new. The history of modern STM in non-Western countries would then be regarded as "an internal and built-in process" in which local agency played a more or less relevant role (Ebrahimnejad, 2005, p. 8).

The development of secular humanitarianism may be taken as an example of social and medical modernisation. Among the various relief organisations founded in Islamic countries in the past two centuries, the Red Cross has figured prominently. Although no Islamic country took part in the international meeting of August 1864 in which the First Geneva Convention was agreed, the Ottoman Empire joined hardly a year after its signature and Qajar Persia followed suit in 1874 (Hüsnü, 2004, p. 22). The self-styled Ottoman Red Crescent (ORC) society (Osmanli Hilal-i Ahmer Cemiyeti) was founded as early as July 1868, even though its actual existence and activities began only eight years later in the course of the Russo-Ottoman War of 1877-78, and would be subsequently interrupted until the Greco-Ottoman War of 1897 and finally until 1911, on the eve of the First Balkan War that definitely consolidated its permanent status
(Hüsnü, 2004, pp. 22-28). The pioneering role of the ORC, which comprised the use of the term "crescent" and the official recognition of a moon-shaped logo, paved the way for other societies in the Islamic world. The Egyptian Red Crescent (ERC) and the Indian Red Crescent came into being in $1911^{1}$ (Tanvir, 2009, p. 394), the Azerbaijan society in 1920 and again in $1922^{2}$ and the Afghan Red Crescent in 1934. In Persia, the denomination and emblem of the Red Lion and Sun Society created in 1922 suited its own local traditions (Kashani-Sabet, 2011, p. 105).

This paper sets out to give an account of the origins of the Red Cross in Morocco. A Moroccan-centered perspective is attempted in order to explore the essential connection of humanitarian plans with local processes of State reform and modernisation. Thus, we must begin by acknowledging that those early projects failed. Unlike other Islamic countries, the adherence of Morocco to the Geneva Convention did not occur until its independence in July 1956. The Moroccan Red Crescent society began its existence only a year later and was recognised by the International Committee of the Red Cross (ICRC) in $1958^{3}$. One of the main reasons for such a delay was the inability of Morocco to maintain its independence and sovereignty. The country was subject to a complex partition by European powers from 1906 onwards, which materialised in a French Protectorate, a Spanish Protectorate (itself divided into a Northern and a Southern area) and the so-called International Zone of Tangier. However, we should refrain from making too sharp a historiographical divide around that event. The very complexity of partition was actually a sign of the weak but nonetheless resilient ${ }^{4}$ agency of Morocco due to the previous existence of a State apparatus with significant administrative and military development, as well as international recognition. The Algeciras Conference of 1906 and the Protectorate Treaties of 1912 could not completely do away with the Moroccan State as they intended. Similarly, early local attempts at joining the Red Cross movement, modest and unsuccessful as they were, would have a lasting influence on the later deployment of the French and Spanish Red Cross and would serve as basis for local projects to create a Red Cross/Crescent during the so-called Rif ${ }^{5}$ War.

\section{REFORM, REGENERATION AND THE RED CROSS IN INDEPENDENT MOROCCO, 1886-1906}

As far as we know, no Sultan of Morocco asked the ICRC for recognition of a Moroccan Red Cross/Crescent society during the $19^{\text {th }}$ century. However, other initiatives in relation to the Red Cross were launched during the reigns of Hassan I (1873-94) and Abdelaziz (18941908). Such initiatives emerged from the convergence of a double impulse. On the one hand, the local pro- 
gramme of reforms which continued the modernisation drive started by Abderrahmane ibn Hicham (1822-59) and Mohammed IV (1859-73) in parallel to and inspired by earlier examples in the Ottoman Empire and Egypt (Miège, 1961; Pennell, 2000; Martínez Antonio, 2011). Reforms focused on the army and State bureaucracy, as well as on diplomacy and the opening of the Moroccan economy to the world market. In the case of the army, European officers were hired and so-called "military missions" were permitted residence in order to train local units (Rollman, 1983; Simou, 1995). Weapons and equipment were purchased abroad and student missions were also sent to various European destinations. In the technical branches of the army (medicine, engineering, artillery), student missions were combined with the creation of local institutions. Military engineers were trained from 1891 in the rifle and ammunition factory of Fez directed by the Italian Artillery Colonel Gregorio Bregoli (Tamburini, 2002; Tamburini, 2011). In Tangier, military physicians had been trained since 1886 in the School of Medicine founded by the Spanish army medical officer Felipe Óvilo (Martínez Antonio, 2009; Martínez Antonio, 2012).

Spain provided the second component for Morocco's early Red Cross initiatives through its plans for intervention in the country during the first decades of the Restoration period started in 1875. In my opinion, Spanish "Africanist" circles based in Madrid institutions such as the Sociedad Geográfica, the Sociedad Española de Africanistas y Colonistas and the Ateneo promoted a programme for "regenerating" Morocco similar to the one conceived for Spain itself (Martínez Antonio, González, 2011). Such a programme was also pursued from Barcelona by the Compañía Transatlántica of the Marquis of Comillas and the Sociedad de Geografía Comercial, as well as by other institutions in the main Spanish cities. The model of "regeneration" was different from that of the "civilising mission" being adopted by Great Britain and France in this period as the ideology of colonial expansion. It was different because Spain was less capable of single-handed coercion in Morocco than the major European powers and because Morocco was a more developed society than others in Asia and Africa which had already been or were in the process of being colonised. Regenerationist strategists longed for exclusive Spanish control of Morocco with a view to creating a so-called "African Spain" (Martínez-Antonio, 2013). However, such control involved, on the one hand, accepting an active participation of Moroccan elites that Spain would undertake to train (government officials, army officers, physicians, engineers). On the other hand, Spain did not intend to dismantle the old State apparatus but to sustain ongoing modernising reforms by improving tax collection, strengthening the army, launching public works programmes, developing education and public health, etc. The benefits would reach some sectors of Moroccan society, and not merely suit Spanish interests.

The convergence of Moroccan reform and Spanish regeneration in the field of secular humanitarianism resulted in the creation of the Tangier Lifeboat Board (Junta de Salvamento de Náufragos) in December $1886^{6}$. Dr. Óvilo, a well-known agent of Spanish Africanist circles in Morocco, and Rodolfo Vidal Batlló, representative of the Compañía Transatlántica in Tangier managed to achieve the Sultan's approval by way of his newly appointed delegate (naib) in the city Sidi Mohammed Torres ${ }^{7}$. In a way, Óvilo and Vidal were transplanting into Morocco a branch of the Spanish Lifeboat Society (Sociedad Española de Salvamento de Náufragos) founded in 1880 by the hydrographer Martín Ferreiro Peralta following European precedents such as the Royal National Lifeboat Institution (1854) in Great Britain and the Société Centrale de Sauvetage de Naufragés (1865) in France (García, 1965). The Sociedad consisted of a central commission in Madrid which coordinated a network of local Juntas established in the main ports of Spain and was declared "a charity of public utility" by the Spanish government in January 1887 (Quero, 2002). However, the Tangier Lifeboat Board was also part of the Moroccan administration because its activities were dependent upon the executive decisions of Moroccan authorities and its non-technical staff included Moroccan representatives. In that sense, it was similar to other mixed Moroccan-Spanish institutions promoted by Óvilo in Tangier such as the School of Medicine and the Chamber of Commerce.

Picture 1. Portrait of Felipe Óvilo in Marrakech, by Enrique Simonet (1894). Source: Courtesy of Milagro Óvilo.

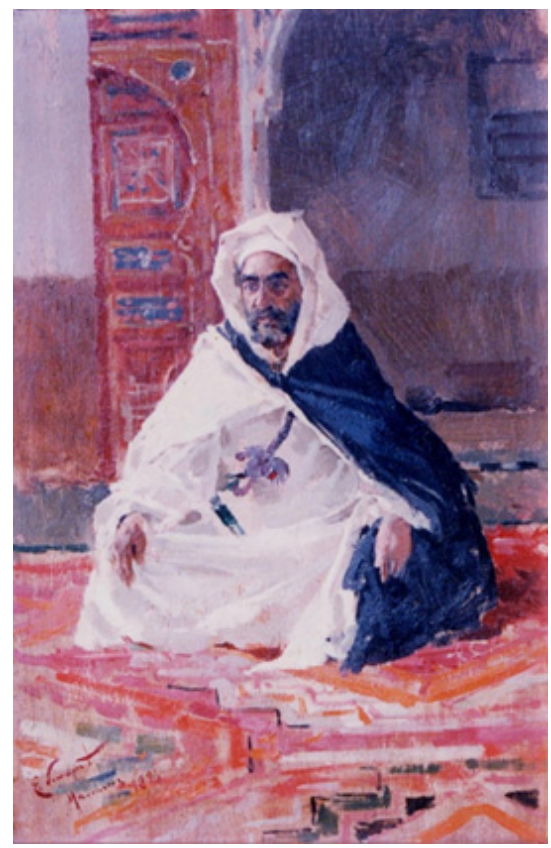


It was a common trend throughout Europe for the charitable nature of shipwreck rescue to gradually intertwine its institutions with those of the Red Cross, especially when the Hague Peace Conference of 1899 "finally extended to war at sea the principles of the 1864 Geneva Convention" (Hutchinson, 1996, p. 195). Thus, the creation of the Lifeboat Board could have had some positive feedback on the creation of a Moroccan Red Cross. Attempts - stemming also from the convergence of reform-regeneration - were actually made for the country to sign up to the Geneva Convention. Although they failed, they would anyhow have a significant impact in the future. Their origin might be traced back to the harsh armed clashes between the Sultan's regular army and Andjera tribesmen that occurred in the vicinity of Tangier in the summer and autumn of 1892. Óvilo, with the help of his colleagues Severo $\mathrm{Ce}$ narro and Sotero García de Mayoral and of his Moroccan disciples trained at the School of Medicine, provided medical assistance to the Sultan's army on the field while also performing surgical operations in the dispensary attached to the above mentioned School. The Spanish and Tangier press portrayed their intervention as a "humanitarian task" in which they had been "very well received" 8 . Óvilo was officially congratulated by the Sultan and praised by the "commanders of the military units that took part in the combat and collectively by the kaids of the mehallas due to his scientific, professional and humane conduct" (Laredo, 1994, p. 170).

In the following years, internal strife grew harsher in Morocco. A raid punished Guelaya tribes which had attacked Spanish troops in the vicinity of Melilla in December 1893; the uprising of the Rehamna tribe in the vicinity of Marrakech in 1896 was bloodily suppressed; a mehalla sent by the Sultan castigated Riffian tribes for their piratical activities in 1898 (Pennell, 2000, pp. 113-114). In this context, Dr. Óvilo must have seriously thought of persuading the Moroccan authorities to create a Red Cross/Crescent society. His plans would be, however, disrupted by the onset of the last war for Cuban independence. Óvilo was unwillingly transferred to Havana in December 1896 and though he was sent back to Spain just six months later due to yellow fever, he decided to leave the army and never resumed his post in Morocco. Despite all, in May 1897 the Central Committee of the Spanish Red Cross (SRC) in Madrid addressed the Ministry of Foreign Affairs to inquire of the new Sultan Abdelaziz the possibility of Morocco's adherence to the Geneva Convention of 1864 or that at least he "gave the orders so that the authorities and armed forces of the Empire respect the immunity of hospitals and ambulances in times of war"9.
Picture 2. Request of the Spanish Red Cross to the Ministry of Foreign Affairs on the adherence of the Sultan of Morocco to the Geneva Convention (May, 1897). Source: AMAEC.

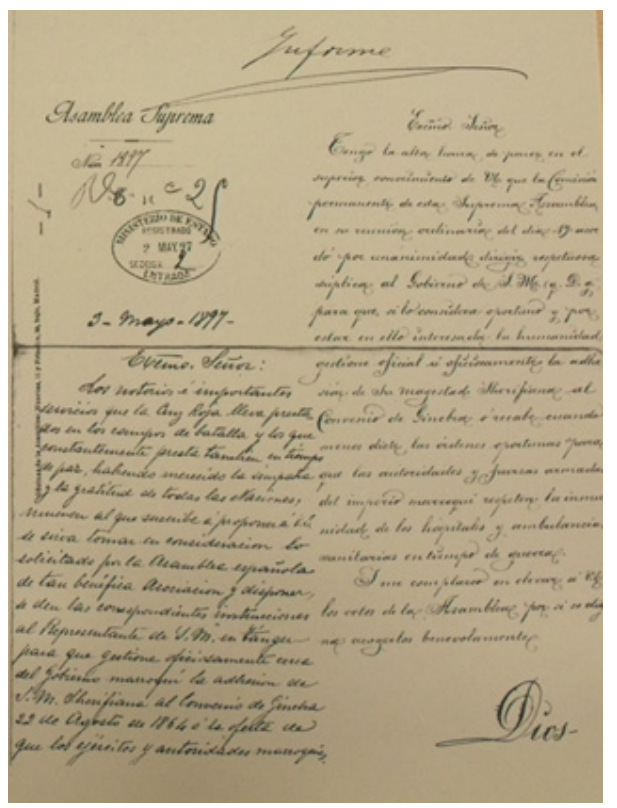

The request was sent to the head of the Spanish Legation in Tangier, Emilio de Ojeda, who presented it in September to the naib Sidi Mohammed Torres and his assistant Sidi Mohammed Lebbadi. The answer subsequently received by Ojeda was negative since the Sultan argued that

despite his best wishes, he could not subscribe to the humanitarian goals pursued by the Central Committee of the SRC, as the irregular nature of the armed contingent in Morocco, mostly composed of qabilas [tribes] which come without any order from all over the country and gather in the battleground, prevented him from undertaking such a commitment ${ }^{10}$.

In June 1899, the president of the Central Committee of the SRC again asked the Ministry of Foreign Affairs to try to convince the Sultan to endorse the Geneva Convention "because of the great interest it [the request] had for humanity"11. The Sultan once more rejected a proposal that would never be offered to him again. It must be pointed out that these démarches were made while General Eusebio Sáenz Sáenz acted as president of the SRC, a transitional two-year period between the long terms of office of General Camilo Polavieja. In February 1897 a commission had been appointed to draft new regulations for the association; although presented in April they would only be passed in August $1899^{12}$. Three of its members, the Army medical officer Gregorio Andrés y Espala, the SRC inspector César Órdax y Avecilla, and especially Rafael Torres Campos, a leading actor in Africanist and regenerationist circles in Madrid, had contacts 
with Óvilo. Even though he had been sent to Cuba, Óvilo could have promoted the SRC initiative through his contacts in the commission or in the association in general ${ }^{13}$. In any case, SRC attempts at persuading the Sultan to sign the Geneva Convention were the climax of a ten-year effort of convergence between Moroccan reform and Spanish regeneration plans in the field of secular humanitarianism. Their failure reflected the damage inflicted upon Spanish influence in Morocco by the wars of independence of Cuba and the Philippines and by the subsequent loss of both overseas possessions. It also reflected how Morocco gradually came to regard immobility instead of reform as the only way to avoid other, more coercive European (non-Spanish) interventions which were now the dominant alternatives on the path to modernisation.

\section{RESILIENT “HUMANITARIAN SOVEREIGNTY" VERSUS FRANCO-SPANISH IMPERIALISM, 1906-1921}

The international conference held at Algeciras in the beginning of 1906 marked the start of a new period in the history of Morocco defined by the final loss of its independence. The establishment of two socalled "zones of influence", one assigned to France, the other to Spain, was agreed at that conference and became the basis for the creation of the French and Spanish Protectorates in 1912 (González Alcantud, Martín Corrales, 2007; Delaunay, 2010, pp. 224-247). The French zone being much larger and more relevant than the Spanish, it reflected the actual takeover of European influence in Morocco in favour of the first country. Despite all, the conference still proclaimed Moroccan sovereignty, especially with regard to the Sultan as religious leader and head of State and to a number of institutions based in Tangier ${ }^{14}$. The Algeciras Act should be thus considered, in my opinion, as the legal embodiment of a weakening though resilient Moroccan sovereignty that the Protectorate Treaties and their ensuing legislation failed to quash completely, thanks in many ways to the long-lasting support provided to it by countries such as Germany, Great Britain or the United States.

Such resilience posed a continuous threat during the early stage of French and Spanish domination. The allocation of spheres of influence to both countries had been agreed for the sake of Moroccan integrity and sovereignty and therefore they were ultimately subject to them. The Algeciras provisions also served as a basis for the exclusion of Tangier and its long-standing institutions from the French and Spanish Protectorates, and were a crucial reason for the uprising of Abdelhafid against his brother Sultan Abdelaziz in 1907-08 and of the Riffian leader Muhammad ibn 'Abd al-Karim al-Khattabi (Abdelkrim for short) in 1921. From the 1930s onwards, Moroccan nationalists would continue to invoke them and
Picture 3. Sidi Mohammed Torres and Moroccan delegates landing at Algeciras to attend the international conference. Source: Le Petit Journal, Supplement de Dimanche, 21/1/1906.

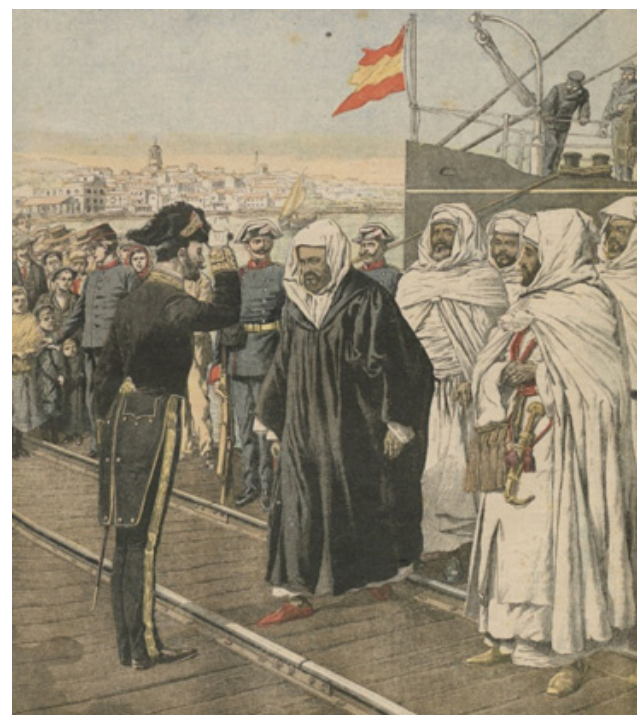

Sultan Mohammed $\mathrm{V}$ did so again in his manifesto for independence delivered in Tangier in 1947. In a different way, Morocco's resilient sovereignty would drive France and Spain to try and extend their imperialist ambitions to Tangier and the part of the country beyond their control. They realised that the only way to hold down the threat of Morocco's agency, would have been to ensure exclusive control over the whole country. Such an a attempt would prove a failure in the end, even for the more powerful French, but it fuelled a sustained competition for hegemony between France and Spain which greatly contributed to what Jean-Marc Delaunay has termed méfiance cordiale (amiable mistrust) between the two countries in the first third of the $20^{\text {th }}$ century (Delaunay, 2010).

Regarding the Red Cross during this period, the chances that the Sultan would sign up to the Geneva Convention and create an official local society faded. However, they were still possible from a legal point of view thanks to the "humanitarian sovereignty" 15 asserted by initiatives taken in previous decades. A reverse proof of that possibility occurred in September 1908 when the creation of a so-called "Red Cross and Lifeboat Board. Morocco" (Sociedad de Cruz Roja y Salvamento de Náufragos. Marruecos) in Madrid was communicated to the diplomatic representatives of Spain, France, Great Britain and Germany in Tangier ${ }^{16}$. Its president was Julio de Lecea y Navas, director of the Academia Heráldica, an institution acting as a higher board of the Order of the Hospitaller Knights of St. John the Baptist, a minor, historically discontinuous branch of the Order of Malta in Spain ${ }^{17}$. The Spanish Legation in Tangier informed the minister of Foreign 
Affairs who forwarded the dispatch to the Central Committee of the SRC. Its president, the Marquis of Polavieja, considered that the Spanish government should immediately proceed to ban that charity because an association established in Spanish territory could not possibly have the right to act on, so it was affirmed, an "independent and sovereign power" as Morocco ${ }^{18}$. The creation of a Red Cross society with the name of that country could only be done locally and needed the Sultan to endorse the new Geneva Convention of July 1906, which he had failed to do, as previously with the first one in 1897 and $1899^{19}$. The SRC should also be regarded as the only Spanish humanitarian association allowed by the government to extend its activities to Morocco because it had enjoyed official status in Spain since 1864. Despite protests, the Red Cross and Lifeboat Society of Morocco continued to exist though it did not undertake any actual initiatives beyond appointing several delegates. It seems to have disappeared after a scandal in $1911^{20}$.

Picture 4. Operating room of the Spanish Red Cross emergency clinic in Tangier, date unknown. Source: Laredo (1994).

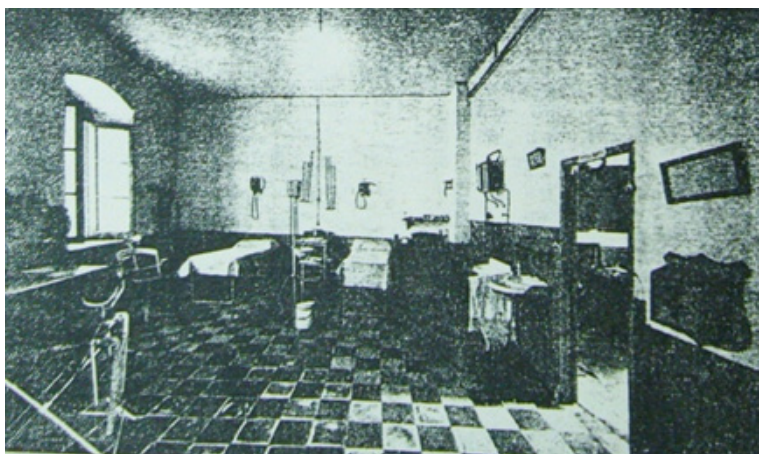

A second, indirect proof of the persistence of Morocco's sovereignty was the stiff though underground competition between the Spanish and the French Red Cross for complete "humanitarian hegemony" in the country. Only after such hegemony had been achieved, could a typically colonial Red Cross have been set up and put to work ${ }^{21}$. However, even France would fall short of the target. Soon after the Algeciras Act had been signed, the French started the occupation of the country through military campaigns which offered a perfect chance for the French Red Cross (FRC) to extend its activities into Moroccan territory ${ }^{22}$. Spain and the SRC followed suit. It soon became clear that neither the FRC nor the SRC would confine their activities to their theoretical areas of influence. Tangier, in particular, became the main locus of competition as both nations realised that the annexation of the city to their Protectorate would strike a decisive blow in their unfailing aspiration to control the whole country. That is why some of the earliest and most important Red Cross initiatives of France and Spain were carried out there. In the French case, they were about to start in 1907, when the secretary of the Sociéte de Secours aux Blessés Militaires General de Valence tried in vain to send the first FRC nurses to Tangier rather than Casablanca, and to ensure the evacuation hospital for casualties suffered during the occupation of the latter city, was established in the former (Bettex, 1908, p. 84). Nurses would be actually sent to Tangier in 1912, shortly after the so-called "Fez mutiny". They remained in the city for several months before moving to the imperial capital, where they were attached to various military hospitals (Lyautey, 1933, p. 732). In February 1918, the local FRC committee presided by Mme. Boissonas, wife of the head of the French Legation, opened the city's first goutte de lait (milk station) $^{23}$. In the case of Spain, the pharmacy $L a$ Cruz Roja began to function in the 1910s and provided drugs to European and Moroccan charity institutions $^{24}$. In 1917, a Casa de Socorro (emergency clinic) was opened where free medical and surgical care was provided for Moroccans and Europeans ${ }^{25}$. In 1920 the SRC opened its own gota de leche (milk station) ${ }^{26}$.

Picture 5. French Red Cross civil and military schemes in Morocco, date unknown. Source: Lyautey (1933).

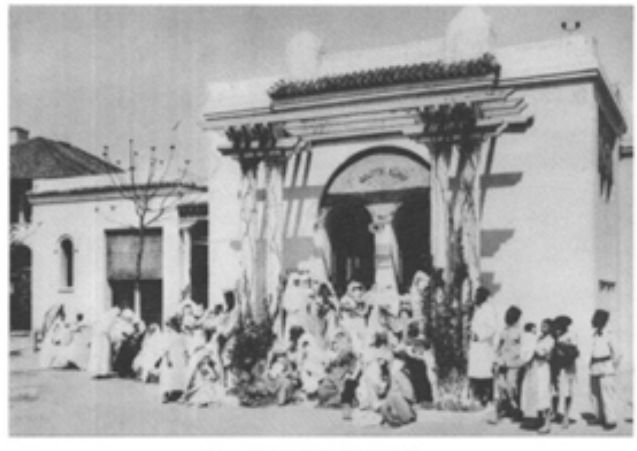

3. - Coutte de lait A Frs.

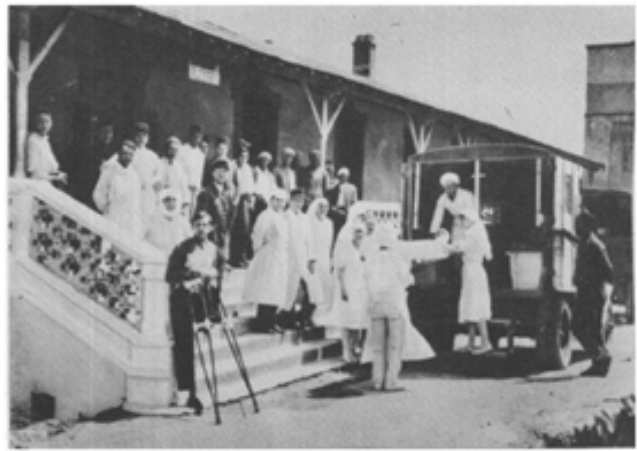

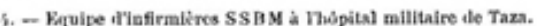


Beyond Tangier, France also led the deployment of pan-Moroccan strategies aimed at winning large territorial and popular support for the cause of the FRC. On the one hand, it readily integrated Red Cross activities into its Protectorate's public health structures so that they helped show the FRC's civilising character in comparison with the militaristic tone of Spanish humanitarian intervention. Since 1911 FRC nurses working in the military hospitals of Rabat and Casablanca had begun to assist Moroccan women who "demanded their services for their sick children"27. Owing to the exceptionally influential position of Mme. Lyautey, head of the FRC in Morocco, after her husband was appointed High Commissioner in 1912, the FRC managed to expand these civil activities by contributing to the development of the official medical care scheme addressed to the Moroccan population, the so-called Assistance Médicale Indigene (AMI) ${ }^{28}$. In 1913, the FRC opened its first dispensary for women and children in Rabat, named "Marie-Feuillet" in memory of a nurse who had died of typhoid fever while assisting French soldiers ${ }^{29}$. A mixed maternal clinic opened in Rabat, adjacent to the dispensary, as well as gouttes de lait in Rabat, Salé, Fez and Casablanca (Fiessinger, 1923, p. 44-47; Woytt-Gisclard, 1936, p. 74, 198-201). A first anti-tuberculosis dispensary was set up in Fez in 1920 followed by another one in Casablanca ${ }^{30}$. Furthermore, France single-handedly promoted the representation of Morocco in international associations, including some in connection with humanitarianism, effectively monopolising the country's outward projection, to the detriment of Spain. For example, Marshall Lyautey "tried to secure Morocco's representation at the Peace Conference of Versailles and its entry into the League of Nations - a move that was blocked by Britain, which feared that Egypt would demand the same" (Bidwell, 1973, p. 18). More successfully, he achieved its admission to the Office Internationale d'Hygiène Publique in 1920 while his wife acted as "Moroccan" representative in the meetings of the Union Internationale contre la Tuberculose of 1924 and $1926^{31}$

\section{CONTINUITIES AND CHANGES: RIFFIAN DEMANDS FOR A RED CROSS/CRESCENT, 1921-1926}

The Rif War opened a new period in the history of Morocco (Ayache, 1996; Pennell, 2001; Madariaga, 2009). It also witnessed the most serious attempt at creating a Red Cross/Crescent society in Morocco before its actual foundation in 1956-57. Such a project showed continuities with previous initiatives, either with regard to the resilience of Morocco's humanitarian sovereignty, or to widespread foreign support and continuing Franco-Spanish competition. However, it was also a product of substantial new developments. The interplay between old and new elements will be briefly sketched in this section. To begin with, it should be stressed that the Riffian leader Abdelkrim based his demand for international recognition of an independent "Rif Republic" on the provisions of the Algeciras Act. In his Declaration of State and Proclamation to All Nations addressed to several European governments and the League of Nations in July 1923, he argued that "before 1906 the actual stand of the Rif regarding this sovereign [the Sultan of Morocco] was almost independent" 32 . After the Algeciras Act which "proclaims the integrity of Morocco throughout all its extent" had been violated by the establishment of the French and Spanish Protectorates, the Rif government, organized as a "modern Republic government" since 1920, had decided to notify "to all Powers that it intends to preserve its political independence absolutely" 33 .

A humanitarian corollary of Abdelkrim's proclamation was no other than the right of the Rif Republic to organize its own Red Cross/Crescent and have it internationally recognised. By contrast with the end of the $19^{\text {th }}$ century, Morocco's humanitarian sovereignty would no longer be in the hands of the Sultan and the State, which lacked legitimacy and agency after becoming subject to Franco-Spanish dictates. Legitimacy now corresponded to the popular Riffian uprising, its charismatic leader and the political-administrativemilitary structures set up in the Rif since 1920. On these grounds, Abdelkrim made repeated attempts throughout the war at founding a Riffian Red Cross/ Crescent. Given the general precariousness of material and human resources which hampered the Riffians during the whole conflict, his main strategy consisted of demanding the ICRC to send a medical mission to the Rif so that it laid the material and human bases for creating a relief organisation on the field while granting it official international status. This appeal to the ICRC would be made at least five times in different forms between 1924 and 1926 .

The first took place in June 1924 when Abdelkrim got in contact with one of his several Moroccan agents in Tangier, Abdelkrim ibn al-Hadj Ali Luh (Sasse, 2005, p. 317). Ali Luh urged Robert Gordon-Canning, a British ex-officer who would later become Abdelkrim's most important foreign representative, to get in touch with his "British friends" in London and "seek every means possible to persuade them to extend their hand to us in politics, also specially in our Red Cross which is in so much need" ${ }^{\prime 34}$. As a result of GordonCanning's demarche, Dr. Ernst H. Griffin, a member of the British private charity British Red Crescent (BRC) and of the Near and Middle East Association (NMEA), addressed the ICRC. He complained of the great suffering of Riffians because "owing to the lack of funds the work of the Red Crescent (or Red Cross) is severely hampered [...] so that the wounded and dying have 
perforce to be left to endure the utmost suffering"35. Thus, he asked the Committee if any medical mission had been sent to the Rif and if not, urged that one was organised "with the utmost speed" ${ }^{36}$. The vice-president of the ICRC, Paul des Gouttes, answered Griffin that no demand for intervention had been hitherto received by the Committee and no inquiry made in consequence. He reminded him that the ICRC could not possibly intervene without "the demand or the formal consent" of the SRC, whose prerogative in the Spanish Protectorate was taken for granted ${ }^{37}$. Despite the negative, Des Gouttes immediately forwarded Griffin's letter to the SRC president the Marquis of Hoyos and asked him if an international relief mission would be accepted ${ }^{38}$. Hoyos replied that all the population in the Spanish Protectorate was duly assisted "by the Spanish government, the makhzen [the Moroccan government under Spanish control] and the SRC"39. Des Gouttes also decided to appoint Raymond Schlemmer as "special delegate" for dealing with the Rif War issues.

In a second move, the Riffians tried to indirectly obtain the ICRC's involvement by persuading the British government either to support a BRC/NMEA medical mission to the Rif, or to undertake its own humanitarian intervention. Foreign relief would trigger the Committee's involvement. Attempts were made at contacting the Foreign Office and a press campaign was started in October 1924 with a letter sent to The Times in which the BRC denounced the suffering of Riffians and their lack of doctors, drugs and medical equipment ${ }^{40}$. Letters were later sent to other newspapers such as The Manchester Guardian, in which allegations were made of gas bombing of civilians by Spanish aeroplanes ${ }^{41}$. However, the British government refused either to grant support for a BRC medical mission, or to intervene directly in the conflict ${ }^{42}$. The third attempt saw a tactical change. The Riffians realised that the unofficial character of the BRC and the NMEA hindered their claims, an obstacle that would be overcome if an official Red Cross society demanded the intervention of the ICRC. In January 1925 they got in touch in Paris with Dr. Lucien Jacquin, a former Troupes Coloniales medical officer who had been stationed in New Caledonia and Morocco - in the latter country he had witnessed first-hand the Fez mutiny of April 1912. Jacquin wrote a letter of denunciation and an appeal for help which he addressed to the Red Cross societies of the Netherlands, Switzerland and Sweden and to the Turkish Red Crescent (TRC) ${ }^{43}$.

As a result, the Swedish Red Cross (SwRC) became the first Red Cross society to officially request information on the Rif War to the ICRC ${ }^{44}$. The Dutch Red Cross declined to take any action but forwarded the letter to the ICRC and the League of Nations ${ }^{45}$. Dr. Akil Muhtar Özen, head of the TRC sent a telegram to the
ICRC informing on Jacquin's letter and reminding that several "Turkish and Muslim countries" had already demanded that a Red Cross medical mission would be sent to the $\mathrm{Rif}^{46}$. Such pressures led the ICRC to elaborate the first report on the Rif War and its démarches in relation to it, which would be published in the February 1925 issues of the Bulletin International des Sociétés de la Croix-Rouge and the Revue Internationale de la Croix-Rouge ${ }^{47}$. The humanitarian claims of the Riffians were thus given a somewhat official character, though no further move was made by the ICRC on the legalistic grounds that it "has never received a direct appeal from the Riffians themselves, and the Central Committees of the aforementioned national societies seem to be in the same case" ${ }^{\prime 4}$. No permission was obtained from Spain either. For the third time, the ICRC contacted the SRC but the Marquis of Hoyos rejected its suggestion responding that the Spanish society would itself proceed to organise and send a medical mission - which it failed to $\mathrm{do}^{49}$.

The Riffians forwarded a fourth request on May 1925, when their military offensive against the French Protectorate was raging. Gordon-Canning, acting now as official foreign representative of Abdelkrim and the Rif government, personally addressed des Gouttes denying that the Riffians had not made a direct appeal for humanitarian assistance to the ICRC ${ }^{50}$. He argued that he himself had been charged with that mission when visiting Tangier and the Rif eighteen months before, a mission reminded to him again by Abdelkrim ibn Jilali and resulting in Dr. Griffin's request of July 1924. Now, to avoid further misunderstandings, Gordon-Canning appealed directly to the ICRC for humanitarian help in the name of the Riffians because it was "more necessary than ever before" 51 . He argued that the Riffians had the right to be assisted by the Committee because they deserved the status of belligerents on three grounds. First, because they had remained "unconquered for 2000 years"; second, because they had always been regarded as bled al-siba (rebellious zone) by the Sultan; and third, because international law stipulated that

\footnotetext{
"the population of a territory which has not been occupied who on the approach of the enemy spontaneously take up arms to resist the invading troops shall be regarded as belligerents if they carry arms openly and respect the laws and customs of war" 52
}

In its reply, Des Gouttes argued again that the ICRC had not been directly addressed by the Rif government. However, in October 1925, shortly before the beginning of the $6^{\text {th }}$ Assembly of the League of Nations in Geneva, the ICRC's president Gustave Ador and the special delegate for the Rif Raymond Schlemmer managed to meet the French prime minister and minister of Foreign Affairs Aristide Briand and the Spanish delegate to the League of Nations José Quiñones de León 
respectively (Durand, 1978, p. 200). They suggested both countries ought to give their permission so that the ICRC could send a medical mission to the Rif with the twofold purpose of providing medical care to Riffian civilians and French and Spanish prisoners of war. Both refused and the Committee decided to send Dr. Henri Mentha as medical delegate to Tangier in November. His report would be published the following month in the ICRC's journal with the title Mission à Tanger (Mentha, 1925). The last appeal for help made by the Riffians would be made in March-April 1926. Taking advantage of the trip to the Rif of Hans Alexander Langlet, correspondent of the Swedish newspaper Dagens Nyheter (Daily News), Abdelkrim handed him a letter for Prince Carl, president of the SwRC ${ }^{53}$.

Picture 6. Original letter sent by Abdelkrim to the Swedish Red Cross (March, 1926). Source: Riksarkivet, Stockholm.

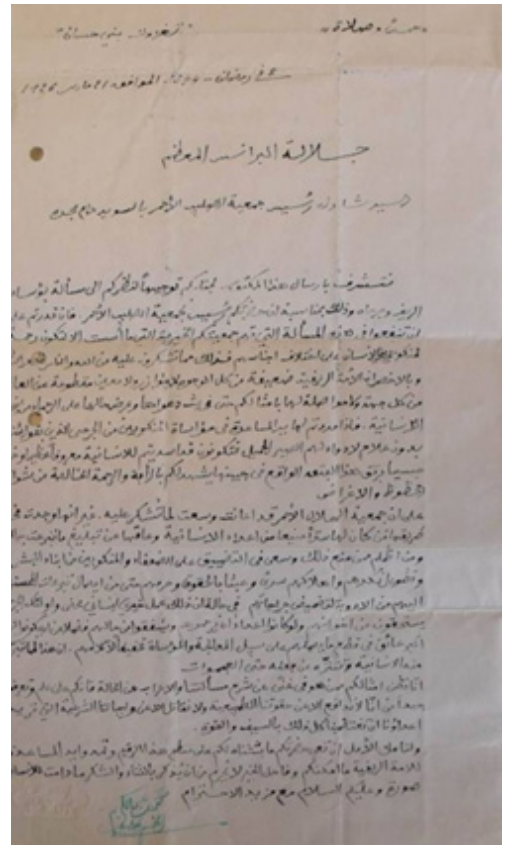

The letter reached Stockholm at the end of April and was forwarded to the ICRC. The Committee felt now legitimised to send a medical mission to the Rif even without the approval of France and Spain, though it looked for and obtained the consent of both countries. Dr. Albert Reverdin, former ICRC delegate in the Balkan Wars, in the Upper Silesia crisis and in the French-occupied Ruhr, was appointed head of the mission (Bouvier, 1929, pp. 92-99). Funds and equipment were requested from the SwRC, the TRC and the Dutch and German Red Cross societies ${ }^{54}$. However, the very moment Reverdin was about to enter the Rif, the French announced Abdelkrim's surrender to its troops. Even though the war dragged on for another year, this put an end to the ICRC mission and to the project of creating a Riffian Red Cross/Crescent.

Apart from the Algeciras Act's statement of Moroccan integrity and sovereignty, the second dimension of Riffian Red Cross initiatives in which elements of continuity and change became intertwined was foreign support. As has already been shown, late $19^{\text {th }}$ century humanitarian projects in Morocco had partly relied on Spanish "regenerationist" intervention. After 1906, Morocco's humanitarian sovereignty would persist thanks to the backing of the Algeciras Act by Germany, Great Britain or the United States against Franco-Spanish exclusivism. The project of a Riffian Red Cross/Crescent would depend on international support to an even larger extent than earlier initiatives, not least due to the structural weakness and contested legitimacy of the Rif Republic in comparison with the old Shariffian Empire. Actually, most relief came from non-official, non-governmental and/or non-Western sources. One of the most relevant was, for example, the previously mentioned British Red Crescent, a private charity funded by wealthy British India Muslims based in London, which had begun its relief operations during the Italian invasion of Tripoli in 1911 and had continued them through the Balkan Wars and the First World War (British Red Crescent, 1915). Substantial aid came also from the ERC, through the initiatives of its president Omar Tousson, to whom we will refer later. Merchants, journalists, arms-dealers, fascist and communist sympathisers and anonymous individuals acted in favour of Riffians or helped spread their claims and appeals to the international community (Sasse, 2005, pp. 69-85).

A third and final axis of continuity and change referred to the sustained competition between France and Spain for complete humanitarian hegemony in Morocco. During the Rif War, French humanitarian interference in Spanish Morocco increased, further diminishing the SRC's prestige by highlighting its inability to fulfil its duties. For example, with regard to the question of prisoners of war, the SRC did not find a solution to the captivity of more than 500 officers, soldiers and civilians in the Rif between July 1921 and January 1923 (Madariaga, 2005, pp. 203249). Abdelkrim rejected all its attempts to release those prisoners and forbade SRC physicians to enter the Rif with relief convoys being regularly sent from the Alhucemas rock. In the end, it was the Basque financier Horacio Echevarrieta who negotiated with Abdelkrim and paid a ransom of several million pesetas. In the middle of that year-and-a-half-long episode, Madame Lyautey met the Spanish King Alfonso XIII in March 1922 in an unofficial visit to Spain with her husband and may have suggested to him that the FRC took control of the problem ${ }^{55}$. Sgt. Francisco Basallo, a prisoner in the Rif, was subsequently told by his 
guards that "France wished to intervene in the provision of food and medical care to the Spanish prisoners by sending FRC nurses, food, clothes, etc. and had asked Abdelkrim for permission" (Basallo, 1923, p. 118). Later on that year, Madame Lyautey surreptitiously reminded the King, by way of the Spanish ambassador in Paris, that "the FRC stood side by side the Spanish society for everything it deemed necessary [in Morocco]" (Angolotti, 1958, p. 109). Her proposals were not taken into consideration.

This episode would be followed by others of a different kind. For example, French Protectorate authorities had been allowing medical personnel, equipment and drugs to enter the Rif from Algeria via the French Protectorate since at least 1922. Abdelkrim's agent in the Oran province, Haddu ibn Hammu, was systematically granted access on the grounds that he conducted "humanitarian missions" (Sasse, 2005, p. $125,157)$. On the other hand, on December 1924 the French prime minister and minister of Foreign Affairs Édouard Herriot was informed by the French consul in Cairo that Prince Omar Tousson planned to send aid to the Riffians ${ }^{56}$. The consul also informed Marshall Lyautey, who said he would not stop relief as long as it consisted merely of drugs and not physicians. After contacts with French authorities, the ERC finally set to organise a "medical mission comprising five physicians, a chemist and forty nurses" scheduled for the end of January $1925^{57}$. Its leader would be the Syrian Mohammed Said el-Din el-Djibaoui, an agent sent by Abdelkrim to raise funds in the Middle East and British India, and the physicians would be students from the Damascus Medical School ${ }^{58}$. The mission was delayed and endured some changes. For example, it arrived at the Rif by sea because Tousson had been chartering boats loaded with guns for Abdelkrim since December 1924 ${ }^{59}$. In March 1925 he bought the yacht Pharaoh and in the summer "Egyptian and Tunisian doctors" were supposedly working in the Rif (Sasse, 2005, p. 78). The French radically changed their previous indulgence of foreign humanitarian aid for the Riffians after Abdelkrim attacked their Protectorate in the spring of 1925. From then on, relief convoys from French Algeria were prevented from entering Morocco and reaching the Rif while the FRC joined the SRC in blocking all international moves to create and recognise a Riffian Red Cross/ Crescent, including an ICRC's medical mission.

\section{CONCLUSION}

Late $19^{\text {th }}$ century plans for joining the Red Cross movement can be taken as another example of independent Morocco's modernizing projects in the field of medicine and public health. Despite their failure to materialize before the Protectorate period they nonetheless paralleled similar, more accomplished developments in leading Islamic countries such as the Ottoman Empire, Egypt and Persia. A weak, problematic, though utterly resilient drive towards modernization would have been the thread connecting the creation of the Tangier Lifeboat Board in 1886, the demarchés for joining the Geneva Convention in 1897-99 and the Riffian demands for a Red Cross/Red Crescent society in 192426 with the creation of the Moroccan Red Crescent in 1956. The focus on Franco-Spanish domination over the country should not dismiss those early events as a mere product of foreign impositions, nor should they be neglected as irrelevant when compared with the multiple and larger activities of the French and Spanish Red Cross societies during the Protectorate period. The history of modern secular humanitarianism in Morocco was also in part a product of Moroccan agency, either stemming from state reforms promoted by the Sultan, or as an expression of popular anti-imperialist demands formulated by insurgent leaders. Morocco's medical history of the $19^{\text {th }}$ and $20^{\text {th }}$ centuries would have had, thus, a self-made, own component of modernity rooted in resilient local agency persistently confronting and influencing foreign pressures and impositions.

\section{ACKNOWLEDGEMENTS}

This paper has been written with the support of a grant from the Marie Curie Intra-European Fellowships for Career Development (IEF) Programme of the European Union. It is also an outcome of the research project "Sanidad militar, medicina de guerra y humanitarismo en la España del siglo XIX" (HAR201124134) funded by the Dirección General de Investigación, MINECO, Spanish Government. 


\section{NOTES}

1 The Egyptian Red Crescent was only recognized by the ICRC in 1924. It was allowed to use a symbol of "decrescent", different from the Ottoman/Turkish society's crescent (Dinstein, Domb, 2011, p. 247)

2 The Azerbaijan society was dissolved when the Soviet Red Army occupied the country and would not be reestablished until 1922. A year later it would be subsumed within the Union of Red Cross and Red Crescent Societies of the USSR where it remained until Azerbaijan's independence in 1991.

3 http://www.croissant-rouge. $m a /$ index.php?option=com content\&view=article\&id=46, [retrieved on 25/7/2013]

4 The term resilience originally had a mechanical sense, meaning the power or ability to return to the original form and position after being bent, compressed, or stretched. In current psychology it is figuratively used to describe how individuals can successfully cope with social disadvantage or highly adverse conditions, including physical and psychological trauma, either returning to a previous "normal" state, or not showing negative effects. See, for example, Werner, Smith (2001). In my opinion, this term could be applied to the social sciences for a better understanding of how certain non-European societies managed to withstand European expansionism either by successfully reasserting themselves in front of it, or by recovering to a significant extent from an actual phase of domination.

5 The Rif is a mountain range which roughly stretches along Morocco's Mediterranean coast between the city of Tangier and the Spanish enclave of Melilla. The Riffians are the Berber/ Amazigh population established in the central and Eastern parts of that region.

6 Al Mogreb al-Aksa, 12/12/1886. It was also called Junta de Salvamento Marítimo (Maritime Rescue Board).

7 Vidal had acted as representative of the Spanish Lifeboat Society in Tangier since at least 1884 . The following year, he had managed to convince local elites to address the Society so that a local board was created in that city. See at Revista de Geografía Comercial, 1 (3) (July 1885), p. 47

8 Al-Mogreb al-Aksa, 4/9/1892; El Día, 31/8/1892; Diario de Córdoba, 2/9/1892; La Época, 1/9/1892.

9 Archivo del Ministerio de Asuntos Exteriores y Cooperación (AMAEC), Archivo Histórico, Legajo H2743 (AMAEC-AH, leg. $\mathrm{H} 2743$, henceforth).

10 AMAEC-AH, leg. H2743.

11 AMAEC-AH, leg. H2743.

12 "Real decreto creando una Comisión encargada de estudiar y proponer al Gobierno las bases para reorganizar la Sección Española de la Asociación internacional de la Cruz Roja", Gaceta de Madrid, 43 (12/2/1897), p. 660; "Bases para la reorganización de la Cruz Roja", Gaceta de Madrid, 241 (29/8/1899), pp. 764-765.

13 Although the commission held twelve meetings between February and April, no proposal regarding Morocco was explicitly discussed. (1901) Actas de la Junta encargada de proponer al gobierno las bases para la reforma de la Cruz Roja Española. Madrid, Antonio Lamas y José María Díaz Impresores. However, members of the commission or of the SRC would have been well aware of Óvilo's plans and acknowledged their usefulness for the organisation at the very moment its sphere of action in Cuba and the Philippines was endangered. It was maybe thought that the reorganisation of the SRC should be accompanied by a shift from expansion in fading overseas possessions to promising African territories.

14 Full text of "General Act of the International Conference of Algeciras, signed April 7, 1906". http://archive.org/stream/jstor-2212340/2212340_djvu.txt, [retrieved on 25/7/2013]

15 The concept of "humanitarian sovereignty" currently has two main, contradictory senses. On the one hand, it refers to the right (and obligation) of the international community to intervene in humanitarian crises, placing a population or territory under its direct control for relief and protection purposes. The second meaning, which is used in this article, refers to the right (and obligation) of a particular State to control or organise relief in its own territory and for the benefit of its own population as opposed to non-consented foreign intervention.

16 Archivo General de la Administración (AGA), Fondo África, $81 / 262$.

17 This branch had been created in 1804 and provided medical assistance to Spanish soldiers during the Spanish-Moroccan War of 1859-60 and the last war for Cuban independence. (1881), Reglamento de los Reales Caballeros Hospitalarios Españoles de San Juan Bautista, Madrid, Academia Heráldica. http://www.orderstjohn.org/osj/spain.htm, [retrieved on 22/07/2013].

18 AMAEC-AH, Leg. H2743.

19 The international congress for revising the 1864 Convention took place in Geneva in June and July of 1906. According to Hutchinson, the new convention "revealed the degree to which the civilising mission of the Red Cross had been adapted to the requirements of states and armies as well as to the lessons of practical experience gained since the 1860s". Hutchinson, 1996, p. 199

20 Delegates were appointed for Belgium, the Low Countries, Algeria and Tunisia. The last was responsible for a scandal in Paris after selling diplomas and decorations of real or virtual honorary and charity associations at high prices for self-profit. Le Matin, 17/4/1911.

21 Unquestioned rights over a territory stood behind the colonial nature of the structure and activities of Red Cross societies such as the Dutch East Indies Red Cross (Indonesia), the Algerian Red Cross or the Indian Red Cross. See, for example, Van Bergen, 1993; Lygrisse, 1983.

22 Further details on the chronology and nature of that extension in Martínez Antonio, in press.

23 http://www.tangeryotrasutopias.com/2009/08/cronologiade-la-obra-social-y-cultural.html, [retrieved on 22/07/2013; Marruecos, I (s.f.), pp. 11-14.

24 AGA, Fondo África, 81/249, Legajo 2662

$25 A B C, 29 / 07 / 1922$ 
26 Archive de Médecine des Enfants, 25 (1922), p. 234.

27 h t t p : / / d a f i na.net / for u m s/ r e a d. php?52,217755,219121, page=3, [retrieved on 28/06/2012].

28 Although the creation of civil hospitals, clinics and dispensaries was supposedly addressed to Moroccans, in fact many of these institutions had a mixed character, assisting both Moroccan and French civilians.

29 Bulletin of the League of Red Cross Societies, 2 (October 1920 December 1921), pp. 293-294.

30 Bulletin mensuel de I'Union des Femmes de France, 4 (35) (23 May 1923), p. 114; (38) (1 August 1923), p. 192.

31 Archive du Ministère des Affaires Étrangères de France (AMAEF), Sous-fonds Maroc 1917-1940, Carton 842; (1927), Proceedings of the Fifth Conference of the International Union against Tuberculosis, New York, National Tuberculosis Association of the United States, p. 41.

32 Declaration of State and Proclamation to All Nations. Ajdir, $10^{\text {th }}$ July 1923 (Christian Era). Archive de la Société de $\mathrm{Na-}$ tions (ASDN), Political R591, Clasement 11, Document 30065, Dossier 12861.

33 Ibidem.

34 Archive du Comité Internationale de la Croix-Rouge (ACICR), CR 138 Riffains (ACICR-CR 138 Riffains, henceforth), I, 94.

35 ACICR-CR 138 Riffains, I, 1.

36 ACICR-CR 138 Riffains, I, 1.

37 ACICR-CR 138 Riffains, I, 2.

38 ACICR-CR 138 Riffains, I, 3.

39 ACICR-CR 138 Riffains, I, 4.

40 The Times, 18/10/1924
41 The Manchester Guardian, 25/11/1924.

42 ACICR-CR 138 Riffains, I, 66.

43 Ibidem.

44 ACICR-CR 138 Riffains, I, 62.

45 ACICR-CR 138 Riffains, I, 66.

46 ACICR-CR 138 Riffains, I, 67

47 "Comité International. Demandes d'intervention. Secours aux blessés du Riff", Bulletin Internationale des Sociétés de la CroixRouge (BISCR), LV, 270; Revue Internationale de la Croix-Rouge (RICR), 74 (February 1925), pp. 113-116.

48 “Comité International”, p. 116.

49 ACICR-CR 138 Riffains, I, 81.

50 ACICR-CR 138 Riffains, I, 94

51 ACICR-CR 138 Riffains, I, 94.

52 ACICR-CR 138 Riffains, I, 94. This provision corresponded to the second article of Chapter 1, Section I (On belligerents) of the Annex to the Convention with Respect to the Laws and Customs of War on Land signed at The Hague on 29 July 1899.

53 ACICR-CR 138 Riffains, I, 199.

54 ACICR-CR 138 Riffains, I, 168.

$55 A B C, 28 / 03 / 1922$.

56 Service Historique de l'Armée de Terre (SHAT), 3H262, 5.

57 Service Historique, 5.

58 Service Historique, 5.

59 The National Archives (NA), Foreign Office, 141-819. 


\section{BIBLIOGRAPHY}

Ada, Hüsnü (2004), The First Civil Society Organization in the Service of the Ottoman State: The Case of the Ottoman Red Crescent (Osmanli Hilâl-i Ahmer Cemiyeti) [online], available at: http:// arsiv.kizilay.org.tr/UserFiles/File/makale/husnu\%20ada\%20tez. pdf, [retrieved on 17/07/2013]

Al-Sayyid, Afaf (1984), Egypt in the Reign of Muhammad Ali, Cambridge, Cambridge University Press.

Anastassiadou-Dumont, Méropi (dir.) (2003), Médecins et ingénieurs ottomans à l'âge des nationalismes, Paris, Maisonneuve \& Larose.

Angolotti, Ignacio (1958), La Duquesa de la Victoria, Madrid, [s.n.].

Ayache, Germain (1996), La Guerre du Rif, Paris, L'Harmattan.

Basallo, Francisco (1924), Memorias del cautiverio (Julio 1921 a Enero 1923), Madrid, Mundo Latino.

Bettex, R. (1908), "Les infirmières de la Croix-Rouge au Maroc”, Annales Politiques et Literaires, 16 (1283), pp. 84-85.

Bidwell, Robin (1973), Morocco under Colonial Rule: French Administration of Tribal Areas 1912-1956, New York, Frank Cass.

Bouvier, Bernard (1929), "Albert Reverdin", Revue Internationale de la Croix-Rouge, 122 (February), pp. 92-99.

British Red Crescent (1915), The Work of the British Red Crescent in Three Continents, 1912-1914, London, [s.n.].

Crozet, Pascal (2008), Les sciences modernes en Egypte. Transfert et appropriation, 1805-1902, Paris, Geuthner.

Delaunay, Jean-Marc (2010), Méfiance cordiale. Les relations franco-espagnoles de la fin du XIXe siècle à 1914. Volume 2: Les relations coloniales, Paris, L'Harmattan.

Dienstein, Yoram; Domb, Fania (eds.) (2011), The progression of international law, Leiden, Brill.

Durand, Andrée (1978), From Sarajevo to Hiroshima: History of the International Committee of the Red Cross, Genève, Comité Internationale de la Croix-Rouge.

Ebrahimnejad, Hormoz (2005), The Development of Modern Medicine in Non-Western Countries: Historical Perspectives, LondonNew York, Routledge.

Fiessinger, Nöel (1923), La médecine française au Maroc, Paris, A. Maloine et Fils.

García, Enric (1965) “La Sociedad Española de Salvamento de Náufragos. Un altre punt de vista sobre la nostra història marítima", Drassana, 4, pp. 8-15.

González Alcantud, José Antonio; Martín Corrales, Eloy (eds.) (2007), La Conferencia de Algeciras en 1906: un banquete colonial, Barcelona, Bellaterra.

Hutchinson, John F. (1996), Champions of Charity. War and the Rise of the Red Cross, Boulder, Westview Press.
Kashani-Sabet, Firoozeh (2011), Conceiving Citizens: Women and the Politics of Motherhood in Iran, Oxford, Oxford University Press.

Laredo, Isaac (1994), Memorias de un viejo tangerino, Rabat, Editions La Porte.

Longuenesse, Elizabeth (dir.) (1995), Santé, médecine et société dans le monde arabe, Paris, L'Harmattan.

Lyautey, Madame (1933), “Exposé de l'action hors de France de la Société de Secours aux Blessés Militaires (Croix-Rouge Française)", Revue Internationale de la Croix-Rouge, 15 (177), pp. 723-744.

Lygrisse, Jean, (1983), Histoire de la sécurite sociale en Algérie, 1830-1962, Paris, Association pour l'Étude de l'Histoire de la Sécurité Sociale.

Madariaga, María Rosa de (2005), En el barranco del Lobo. Las guerras de Marruecos, Madrid, Alianza Editorial.

Madariaga, María Rosa de (2009), Abdelkrim el Jatabi, la lucha por la independencia, Madrid, Alianza Editorial.

Martínez Antonio, Francisco Javier (2009), "Regeneracionismo, sanidad y discurso racial: Felipe Óvilo Canales y la confluencia entre España y Marruecos a finales del siglo XIX", Dynamis, 29, pp. 73-94.

Martínez Antonio, Francisco Javier (2011), Regenerar España y Marruecos. Ciencia y educación en las relaciones hispano-marroquies a finales del siglo XIX, Madrid, CSIC-Casa Árabe.

Martínez Antonio, Francisco Javier (2012) “The Tangiers School of Medicine and its Physicians: A Forgotten Initiative of Medical Education Reform in Morocco", Journal of the International Society for the History of Islamic Medicine, 10-11 (19-22), pp. 80-86.

Martínez Antonio, Francisco Javier (2013), "Vom Spanien in Übersee zum Spanien in Afrika : Über die Eigentumlichkeit des spanischen Imperiums im 19. Jahrhundert", Mittelweg 36. Zeitschrift des Hamburger Instituts für Sozialforschung, 22 (6), pp. 18-35.

Martínez Antonio, Francisco Javier (in press), "Weak Nation-States and the Limits of Humanitarian Aid: the case of Morocco's Rif War, 1921-27". In: Johannes Paulmann (coord.) The Dilemmas of International Humanitarian Aid in the $20^{\text {th }}$ century, Oxford, Oxford University Press.

Mentha, Henri (1925), "Mission à Tanger", Revue Internationale de la Croix-Rouge, 7 (84), pp. 971-981.

Moreau, Odile (2007), L'Empire ottoman à l'âge des réformes. Les hommes et les idées du «Nouvel Ordre» militaire, Paris, Maisonneuve \& Larose.

Moreau Odile (dir.) (2009), Réforme de l'État et réformismes au Maghreb (XIXe-XXe siècles), Paris, L'Harmattan-IRMC.

Moulin, Anne-Marie; Ulman, Yesim Isil (2010), Perilous Modernity. History of Medicine in the Ottoman Empire and the Middle East from the 19th Century Onwards, Istanbul, The Isis Press. 
Pennell, Charles R. (2000), Morocco since 1830. A history, London, C. Hurst \& Co.

Pennell, Charles R. (2001), La Guerra del Rif: Abdelkrim el Jatabi y su Estado rifeño, Melilla-Ceuta, Servicio de Publicaciones de la Ciudad Autónoma de Melilla/Centro Asociado a la UNED de Melilla/Consejería de Cultura de Ceuta.

Quero, Manuel (2002), "La Sociedad Española de Salvamento de Náufragos", Aljaranda. Revista de Estudios Tarifeños, 12 (47), pp. 28-35.

Raj, Kapil (2010), Relocating Modern Science: Circulation and the Construction of Knowledge in South Asia and Europe, 16501900, London, Palgrave-MacMillan.

Rollman, Wilfrid J. (1983), The 'New Order' in a pre-colonial Muslim society: military reform in Morocco, 1844-1904, 2 vols, Ann Arbor, University of Michigan.

Sasse, Dirk (2005), Franzosen, Briten und Deutsche im Rifkrieg, 1921-1926, München, Oldenburg Verlag.

Simou, Bahija (1995), Les reformes militaires au Maroc de 1844 à 1912, Rabat, Université Mohammed V.
Tamburini, Francesco (2002), "La Regia Missione Militare in Marocco (1888-1915). Note su un fallimento italiano", Africana, 7, pp. 133-146.

Tamburini, Francesco (2011), “Las armas italianas del sultán: la política exterior del Reino de Italia en el Imperio jerifiano a finales del siglo XIX". In: Francisco Javier Martínez Antonio, Irene González González (coords.) Regenerar España y Marruecos. Ciencia y educación en las relaciones hispano-marroquíes a finales del siglo XIX, Madrid, CSIC-Casa Árabe, pp. 123-140.

Tanvir, Syed (2009), "The Indian Red Crescent Mission to the Balkan Wars", Middle Eastern Studies, 45 (3), pp. 393-406.

Van Bergen, Leo (1993), "For our honor and our rights: the Dutch East Indies Red Cross and the first Atjeh expeditions". In: Rudolf Dekker (ed.), Curing and Insuring: Essays on IIlness in Past Times. The Netherlands, Belgium, England and Italy, $16^{\text {th }}-20^{\text {th }}$ centuries, Hilversum, Verloren, pp. 135-150.

Werner, E. E.; Smith, R. S. (2001) Journeys from childhood to midlife: Risk, resiliency, and recovery, Ithaca, Cornell University Press.

Woytt-Gisclard, Alix (1936), L'assistance aux indigènes musulmans au Maroc, Paris, Librairie du Recueil Sirey. 